\title{
KARAKTERISASI SIFAT SENSORIS, PROKSIMAT, ANTIOKSIDAN, TOTAL BAL, DAN UJI PASAR ES KRIM BERBAHAN PUREE DAN BUBUK MANDAI CEMPEDAK
}

\section{CHARACTERIZATION OF SENSORY, PROXIMATE, ANTIOXIDANT, TOTAL LAB AND MARKET TEST FOR ICE CREAM CONTAINING PUREE AND POWDER OF MANDAI CEMPEDAK}

\author{
Anton Rahmadi, Farezza Afia Rohmatul Firdaus dan Marwati \\ Jurusan Teknologi Hasil Pertanian, Fakultas Pertanian,Universitas Muawarman \\ Jl. Muara Pahu, Gedung OECF, Samarinda \\ Alamat Email: arahmadi@unmul.ac.id
}

\begin{abstract}
ABSTRAK
Mandai cempedak merupakan produk hasil fermentasi bakteri asam laktat yang berasal dari kulit bagian dalam buah cempedak (Artocarpus champeden). Penelitian ini bertujuan untuk melakukan formulasi es krim berbahan puree atau bubuk mandai cempedak yang kemudian diuji penerimaan konsumennya dalam skala lab dengan jumlah panelis 35 orang pada rentang usia 17-21 tahun, dilanjutkan dengan pengamatan profil proksimat (kadar air, kadar abu, kadar protein, lemak, dan karbohidrat), antioksidan, total bakteri asam laktat (BAL), dan uji penerimaan pasar dengan jumlah respoden 60 orang. Analisis lanjutan terdiri dari antioksidan metode DPPH, daya leleh, dan angka lempeng total BAL. Formula terbaik dari kelompok bahan puree dan bubuk mandai cempedak diujikan kepada masyarakat umum dengan teknik uji konsumen dengan penilaian hedonik dengan parameter rasa, tekstur dan aroma, juga pendapat masyarakat secara umum akan kemampuan bersaing dan harga jual potensial produk ini. Penggunaan puree mandai cempedak pada konsentrasi $100 \mathrm{~g}$ per formula merupakan pilihan konsumen yang secara hedonik mampu bersaing dengan produk komersial yang diujikan dengan daya leleh es krim mandai cempedak berkisar 16 s.d. 17 menit. Karakteristik es krim puree mandai cempedak adalah kadar air sebesar 62,25 $\pm 0,07 \%$, kadar abu sebesar

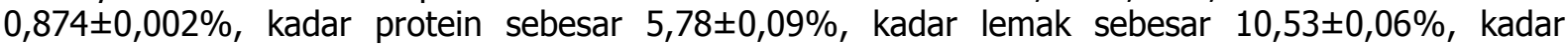
karbohidrat sebesar $26,35 \pm 0,05 \%$, total BAL sekitar 4 skala log $\mathrm{cfu} / \mathrm{mL}$, dan $\mathrm{IC}_{50}$ terhadap penghambatan DPPH sebesar $66,67 \pm 0,19 \mathrm{ppm}$. Es krim dengan cita rasa baru yang berasal dari mandai cempedak memiliki potensi untuk dipasarkan dengan harga kurang dari Rp. 20.000 per kemasan $200 \mathrm{~mL}$.
\end{abstract}

Kata kunci: analisis proksimat, es krim, mandaicempedak, tes pasar

\begin{abstract}
Mandai cempedak is a lactic acid bacteria fermented product originated from the inner skin of cempedak (Artocarpus champeden) fruit. The aim of this research was to produce formulations of ice cream with the addition of mandai puree or powder which were then tested by consumer acceptance in lab scale with 35 participants in the age range of 17-21 years, followed by observation of proximate (moisture, ash, protein, fat, and carbohydrate contents), antioxidant, total lactic acid bacteria (BAL), and a market acceptance test with 60 panelists. The subsequent analysis consisted of antioxidant methods of DPPH, melting duration test, and total BAL plate count. The best formula was tested to the general public by consumer test techniques with hedonic judgment on taste, texture and aroma parameters, as well as general public opinion of competitive ability and potential selling price of this product. The use of puree mandai cempedak at $100 \mathrm{~g}$ concentration per formula was the consumer choice which was able to compete with commercial product tested. The melting duration for ice cream mandai cempedak was from 16 to 17 minutes. Characteristics of ice cream with mandai cempedak puree were $62.25 \pm 0.07 \%$ of moisture, $0.874 \pm 0.002 \%$ of ash, $5.78 \pm 0.09 \%$ of protein, $10.53 \pm 0.06 \%$
\end{abstract}

66 Anton Rahmadi, Farezza Afia Rohmatul Firdaus, dan Marwati

Karakterisasi Sifat Sensoris, Proksimat, Antioksidan, Total Bal, dan

Uji Pasar Es Krim Berbahan Puree dan Bubuk Mandai Cempedak 
of fat, $26.35 \pm 0.05$ of carbohydrate, 4 scale $\log \mathrm{cfu} / \mathrm{mL}$ of $B A L$, and $\mathrm{IC}_{50}$ to $\mathrm{DPPH}$ inhibition equaled to $66.67 \pm 0.19 \mathrm{ppm}$. The new ice creamproduced from mandai cempedak has the potential to be marketed with price range below Rp. 20,000 per $200 \mathrm{~mL}$ of pack size.

Keywords: mandai cempedak, market test, ice cream, proximate analysis

\section{PENDAHULUAN}

- s krim merupakan produk yang populer di seluruh dunia. Cita rasa es krim mulai diperkaya dengan buah-buahan lokal, seperti anggur, kismis, dan tetes tebu (Soukoulis dan Tzia, 2018), maupun durian, nangka, ketan hitam, nanas madu, dan buah-buahan tropis lainnya (Chauliyah dan Murbawani, 2015). Cempedak (Artocarpus champeden) merupakan salah satu kandidat cita rasa buah untuk es krim yang belum banyak dikembangkan. Maksud penambahan buah-buahan pada es krim cukup beragam, termasuk diantaranya meningkatkan potensi antioksidan pada es krim (Cakmakci et al., 2015). Hasil penelitian Rahmadi dkk (2017) menunjukkan bahwa produk hasil fermentasi cempedak yang dikenal sebagai mandai cempedak ternyata memiliki potensi antioksidan dengan kekuatan sedang. Selain itu, penggunaan susu dan bahan hasil fermentasi BAL dapat meningkatkan potensi probiotik dari es krim mandai cempedak, sebagaimana yang diamati pada produk olahan yang sejenis (Silva et al., 2015;Fonseca et al., 2016).

Mandai cempedak merupakan hasil fermentasi bakteri asam laktat (BAL) secara spontan maupun dengan kultur pemula dapat menjadi alternatif cita rasa baru pada es krim khas daerah, karena produk mandai cempedak sendiri cukup popular di masyarakat (Emmawati dkk, 2015; Nur, 2009). Proses pembuatan mandai cempedak secara umum dilakukan dengan menambahkan garam pada konsentrasi $15-25 \%$ (b/b) pada kulit bagian dalam buah cempedak. Pengembangan pengolahan mandai cempedak rendah garam dilaporkan oleh Nur (2009). Teknik pengolahan higienis tanpa garam dan penambahan kultur pemula telah dilakukan oleh Rahmadi dkk (2017).Tahapan introduksi cita rasa es krim baru terdiri dari formulasi, penetapan formula terbaik berdasarkan uji penerimaan atau kesukaan, pengujian kadar nutrisi makro, produksi terbatas, dan pengujian pasar secara terbatas. Pengembangan produk ini menitik beratkan penerimaan masyarakat terlebih dahulu, sebelum produksi dalam skala yang lebih besar (Dertli et al., 2016; Patelet al., 2015).

Penelitian ini bertujuan untuk mendapatkan formulasi es krim terbaik dengan penambahan puree atau bubuk mandai cempedak yang kemudian diujipenerimaan konsumennya dalam skala lab dengan jumlah panelis 35 orang pada rentang usia 17-21 tahun, dilanjutkan dengan pengujianprofil proksimat, antioksidan, total BAL, dan uji penerimaan pasar dengan jumlah respoden 60 orang untuk menentukanes krim mandai cempedak yang berkualitas.

\section{BAHAN DAN METODE \\ Waktu dan Tempat}

Penelitian ini dilakukan pada bulan Desember 2017 sampai dengan Mei 2018, bertempat di Laboratorium Pasca Panen dan Pengemasan Hasil Pertanian, Jurusan Teknologi Hasil Pertanian, Fakultas Pertanian, Universitas Mulawarman.

\section{Bahan dan Alat}

Bahan yang digunakan dalam penelitian ini adalah buah cempedak, susu full cream (Indomilk, PT. Indolakto) dan susu skim curah. Bahan penolong terdiri dari gula kristal putih (PT. Sugar Group Companies), garam, karboksi metil selulosa (CMC) (PT. Gunacipta Multirasa), emulsifier basis ester asam lemak dan sorbitan (SP) (PT. Gunacipta Multirasa), dan lesitin kedelai (PT. Anugrah Putra Kencana). Bahan-bahan untuk analisis terdiri dari de mann rogosa sharpe agar (MRSA) (HiMedia, India), kit pewarnaan Gram (HiMedia, India), iodin, n-heksana (Fulltime, China), alkohol (SmartLab, Indonesia), aquadest, 2,2-dipheny-1- 
picrylhydrazyl (DPPH) (Sigma-Aldrich, USA). Alat utama yang digunakan dalam pembuatan mandai terdiri dari; blender, lemari pembeku $\left(-16 \pm 2^{\circ} \mathrm{C}\right)$, dan oven listrik.Alat untuk analisis terdiri dari hot plate, preparat, colony counter, mikroskop (Olympus CX21), bunsen, buret, vortex, spektrofotometer cahaya tampak (Genesis 20 Thermo Spectronic), timbangan analitik (Mettler Toledo Classic Light AL 204), tanur dan desikator.

\section{Desain Penelitian}

Metode yang digunakan dalam penelitian ini menggunakan Rancangan Acak Lengkap (RAL) faktor tunggal yaitu komposisi puree atau bubuk mandai cempedak yang terdiri dari (I) kontrol es krim, (II) penambahan puree mandai $50 \mathrm{~g}$ dan $50 \mathrm{~g}$ susu skim sebagai pengisi, (III) penambahan puree mandai $100 \mathrm{~g}$, (IV) penambahan bubuk mandai $50 \mathrm{~g}$ dan $50 \mathrm{~g}$ susu skim sebagai pengisi, dan (V) penambahan bubuk mandai $100 \mathrm{~g}$. Ulangan dilakukan sebanyak 3 kali. Data numerik yang diperoleh diolah dengan Analisis Varians (ANOVA) atau T-test. Jika terdapat perbedaan yang nyata pada taraf a 5\%, maka dilanjutkan dengan Uji Beda Nyata Terkecil (BNT). Data non numerik yang terdiri dari sifat sensoris meliputi: tekstur, warna, rasa dan aroma dengan skala mutu hedonik. Skala mutu hedonik untuk rasa terdiri dari berasa susu (1) sampai dengan berasa mandai (5), untuk tekstur: sangat tidak lembut (1) sampai dengan sangat lembut (5), untuk aroma: beraroma susu (1) sampai dengan beraroma mandai (5), dan untuk warna: pucat (1) sampai dengan coklat-karamel (5).Skala hedonik dideskripsikan sebagai tidak suka (1), agak suka (2), suka (3), dan sangat suka (4). Selanjutnya, penilaian hedonik dan mutu hedonic dianalisis secara deskriptif kemudian ditransformasi ke dalam skala interval dengan teknik transformasi Kruskal Wallis dan dilanjutkan dengan Analisis Varians (ANOVA) non-parametrik atau Ttestjamak untuk menentukan perlakuan yang terbaik pada aplikasi Graphpad Prism ${ }^{\circledR}$ versi 6.0 .

\section{Penyiapan dan Fermentasi Mandai Cempedak}

Kulit buah cempedak yang digunakan merupakan kulit bagian dalam yang telah disortasi dan dibersihkan. Kulit cempedak kemudian dipotong dengan ukuran $3-4 \mathrm{~cm}^{3}$. Setelah itu, potongan kulit cempedak direbus pada suhu $100^{\circ} \mathrm{C}$ selama 5 menit untuk kemudian ditiriskan. Pengolahan kulit cempedak dan induksi mikrobia untuk fermentasi sesuai dengan prosedur yang ditulis dalam aplikasi HKI No. S00201708792.

\section{Pembuatan Bubuk Mandai Cempedak}

Langkah pertama yang dilakukan adalah menyiapkan mandai cempedak untuk ditiriskan, kemudian dilakukan penghalusan dengan cara diblender. Bubur (puree) mandai cempedak kemudian dikeringkan selama 18 jam pada suhu $45^{\circ} \mathrm{C}$. Selanjutnya, mandai cempedak yang telah kering dihancurkan dengan cara diblender. Setelah hancur, bubuk mandai cempedak diayak dengan saringan berukuran 80 mesh. Kemudian dilakukan penimbangan berat akhir sampel.

\section{Pembuatan Es Krim}

Bahan-bahan yang terdiri dari susu bubuk skim, susu full cream, gula dan garam. Komposisi lengkap dari es krim akan diajukan sebagai hak atas kekayaan intelektual (HKI). Kemudian, ke dalam adonan ditambahkan mandai cempedak yang telah diblender menjadi bubur (puree) atau bubuk mandai sesuai perlakuan. Setelah itu, adonan didinginkan dalam wadah sambil dimixer selama \pm 15 menit pada kecepatan sedang. Kemudian adonan disimpan di dalam freezer $\left(-16 \pm 2^{\circ} \mathrm{C}\right)$ selama \pm 2 jam untuk proses aging. Adonan yang telah dingin kemudian dihomogenisasi menggunakan mixer selama \pm 15 menit. Lalu, adonan dikemas dalam wadah (cup), kemudian simpan didalam freezer.

\section{AnalisisProduk}


Analisis yang dilakukan meliputi uji mutu hedonik untuk mendapatkan formulasi es krim dengan puree dan bubuk mandai cempedak yang berasa mandai cempedak, bertekstur lembut, dan beraroma dominan mandai cempedak. Penilaian terhadap mutu hedonik warna ditampilkan sebagai referensi produk akhir yang diharapkan konsumen. Analisis lanjutan pada dua formulasi terbaik, yaitu satu formulasi es krim berbahan puree mandai cempedak dan satu formulasi es krim berbahan bubuk mandai cempedak, terdiri dari analisis antioksidan metode DPPH (Molyneux, 2004), kadar air, kadar abu, kadar protein, lemak, dan karbohidrat (BSN, 1992), uji daya leleh (Oksilia dkk, 2012), kemudian uji angka lempeng total BAL (Fardiaz, 1993). Perlakuan terbaik diujikan kepada masyarakat umum dengan teknik uji konsumen dengan penilaian hedonik dengan parameter rasa, tekstur dan aroma.

\section{Aktivitas Antioksidan}

Uji aktivitas antioksidan dilakukan dengan metode 2,2-dipheny/1-picrylhydrazy (DPPH) (Molyneux, 2004). Sebanyak $1 \mathrm{~mL}$ sampel es krim dimasukkan ke dalam tabung reaksi kemudian ditambah dengan $7 \mathrm{~mL}$ metanol.Setelah itu, ke dalam campuran ditambahkan 2 $\mathrm{mLDPPH}$, sehingga konsentrasi akhir DPPH adalah 0,2 mM.Kemudian sampel di-vortex 2-5 menit dan didiamkan selama 30 menit pada suhu ruang $\left(28 \pm 2{ }^{\circ} \mathrm{C}\right)$. Setelah itu, absorbansi diukur pada panjang gelombang $517 \mathrm{~nm}$. Aktivitas antioksidan dinyatakan dalam presentase penghambatan terhadap radikal DPPH (scavenging activity) dengan perhitungan sebagai \%kapasitas antioksidan.

$$
\text { \%-kapasitas antioksidan }=\frac{(\text { Absorbansi } \text { kontrol }- \text { Absorbansi sampel })}{\text { Absorbansi sampel }} \times 100
$$

Absorbansi kontrol adalah absorbansi DPPH + metanol

Absorbansi sampel adalah absorbansi DPPH radikal + sampel.

\section{HASIL DAN PEMBAHASAN \\ Parameter Hedonik}

Es krim yang lebih disukai adalah dengan penambahan puree mandai cempedak sebanyak $100 \mathrm{~g}$, yaitu dengan nilai rasa $4,15 \pm 0,85$ dan dengan penambahan bubuk mandai $50 \mathrm{~g}$ dengan nilai rasa $3,97 \pm 0,88$. Berdasarkan penilaian hedonik tekstur es krim dengan penambahan puree mandai dan bubuk mandai, perlakuan penambahan bubuk mandai $100 \mathrm{~g}$ merupakan formula yang tidak disukai, dengan nilai tekstur $2,07 \pm 1,05$, atau jatuh pada skala tidak lembut. Penambahan puree atau bubuk mandai cempedak pada setiap formula berhasil membawa cita rasa es krim yang khas, salah satunya es krim dengan puree mandai

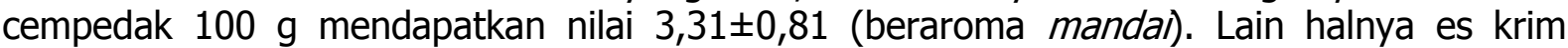
dengan bubuk mandai cempedak yang kehilangan aroma khasnya akibat proses pengeringan dan lebih cenderung beraroma susu. Puree atau bubuk mandai cempedak dapat mempengaruhi warna es krim. Pada es krim dengan bubuk mandai cempedak $100 \mathrm{~g}$ dan $50 \mathrm{~g}$ warna yang timbul adalah kuning kecoklatan, sementara pada es krim dengan puree mandai cempedak $100 \mathrm{~g}$ berwarna kuning dengan nilai 2,72 $\pm 0,52$ (Gambar 1). Tidak semua cita rasa es krim dapat diterima konsumen. Sebagi contoh, konsumen tidak menyukai cita rasa es krim kismis dibandingkan es krim anggur, sementara kismis merupakan anggur yang dikeringkan. Faktor rasa yang berpengaruh diantaranya astringency, dan sensasi rasa asam (sourness sensation). Faktor tekstur yang mempengaruhi diantaranya adalah tekstur yang terasa kasar di lidah (coarseness), kristal es yang tidak halus (iciness)(Ordonez et al., 2000). Hasil penelitian ini mirip dengan formulasi es krim dengan penambahan puree atau bubuk mandai cempedak (Gambar 1), yaitu es krim dengan mandai cempedak tanpa pengeringan secara umum lebih disukai dari es krim dengan bubuk mandai cempedak. Penambahan gum diyakini dapat meningkatkan penerimaan terhadap es krim mandai 
cempedak sebagaimana yang diamati pada es krim bercita rasa asam (Soukoulis dan Tzia, 2008).

\section{Proksimat dan Antioksidan}

Dari dua bahan yang berbeda, yaitu puree dan bubuk mandai cempedak, penambahan puree mandai $100 \mathrm{~g}$ dan bubuk mandai $50 \mathrm{~g}$ dengan bahan pengisi $50 \mathrm{~g}$ susu skim terpilih sebagai formula terbaik untuk masing-masing bahan baku cita rasa baru pada es krim. Kemudian, analisis proksimat dan kadar antioksidan dilakukan pada kedua formula terpilih untuk mendapatkan satu formula terbaik di antara puree dan bubuk mandai cempedak. Kandungan air pada es krim puree mandai cempedak $100 \mathrm{~g}$ adalah $62,25 \pm 0,07 \%$, sedangkan pada es krim bubuk mandai adalah $55,77 \pm 0,06 \%$, atau lebih tinggi secara signifikan $(\mathrm{P}<0,05)$ dibandingkan es krim dengan bahan puree mandai cempedak. Sekalipun berbeda nyata secara statistik $(\mathrm{P}<0,05)$, kandungan kadar abu pada kedua formula es krim berbahan baku puree dan bubuk mandai cempedak secara persentase cenderung mendekati 0,8\%.
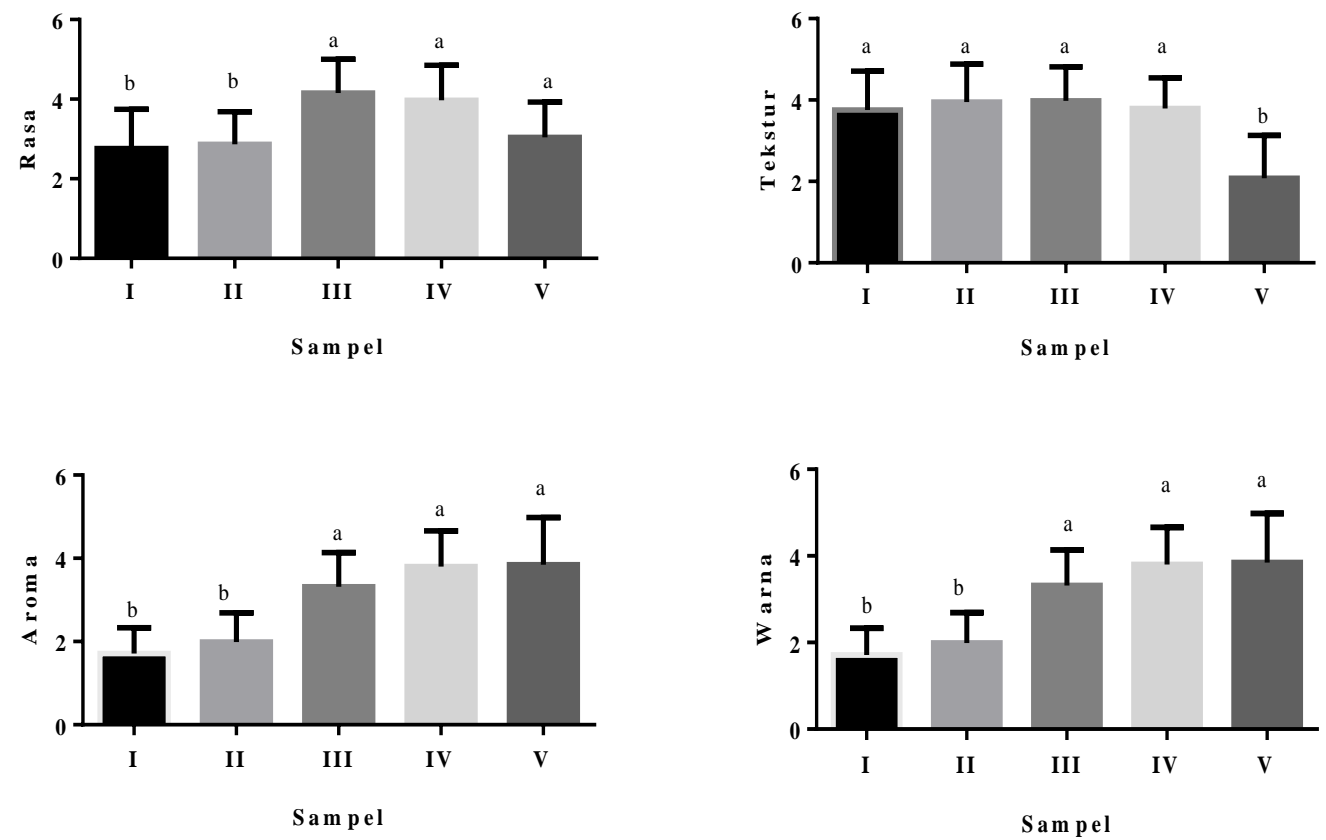

Gambar 1. Penambahan puree atau bubuk mandai cempedak terhadap sifat sensoris es krim.

Keterangan: Skala hedonik untuk rasa: berasa susu (1) s.d. berasa mandai (5), untuk tekstur: sangat tidak lembut (1) s.d. sangat lembut (5), untuk aroma: beraroma susu (1) s.d. beraroma mandai (5), dan untuk warna: pucat (1) s.d. coklat-karamel (5). Standard error of mean (SEM) ditampilkan dengan simbol ( $\mathrm{T}$ ) di atas grafik. Angka rata-rata yang diikuti dengan huruf yang sama menunjukkan tidak berbeda nyata pada taraf alpha $5 \%$ dengan metode Kruskal Wallis. Jumlah panelis adalah 35 orang.

Es krim puree mandai memiliki kadar abu 0,874 $\pm 0,002 \%$ dan pada es krim bubuk mandai adalah $0,812 \pm 0,0 \%$. Pada kedua sampel tersebut kandungan kadar abu berbeda nyata. Es krim dari puree mandai mempunyai kandungan kadar protein sebanyak $5,78 \pm 0,09 \%$ dan pada es krim bubuk mandai adalah 8,32 $\pm 0,04 \%$. Kadar lemak pada es krim dari puree mandai adalah 10,53 $\pm 0,06 \%$, sementara kadar lemak pada pes krim bubuk mandai adalah $7,29 \pm 0,06 \%$. Kandungan karbohidrat pada es krim dengan penambahan puree mandai dan bubuk mandai adalah $26,35 \pm 0,05 \%$ dan $36,12 \pm 0,12 \%$. Ini berarti, es krim bubuk mandai lebih banyak mengandung karbohidrat apabila dibandingkan dengan es krim dari pureee mandai. Es krim yang terbuat dari puree mandai $100 \mathrm{~g}$ memiliki nilai aktivitas antioksidan tertinggi dengan nilai IC $_{50}$ terhadap penghambatan DPPH sebesar 
$66,67 \pm 0,19$ ppm, sedangkan pada es krim dari bubuk mandai memiliki nilai aktivitas antioksidan 42,65 $\pm 0,19$ ppm (Gambar 2).

Es krim mandai cempedak termasuk dalam terminologi es krim rendah lemak, yaitu mengandung 6 s.d. 14\% lemak (Tekin et al., 2017). Standar produk olahan es krim dijelaskan dalam SNI No. 01-3713-1995 (BSN, 1995). Penambahan puree maupun bubuk mandai cempedak ternyata meningkatkan kadar karbohidrat disbanding standar SNI es krim, sebagaimana yang diamati pada produk es krim dengan bahan baku substitusi susu skim dengan inulin ataupun hidrokoloid (Soukoulis et al., 2010;El-Nagar et al., 2016). Es krim dengan bahan baku bubuk mandai cempedak cenderung lebih padat dibandingkan dengan yang berbahan baku puree mandai cempedak oleh sebab peningkatan kadar karbohidrat dan protein (Gambar 2).

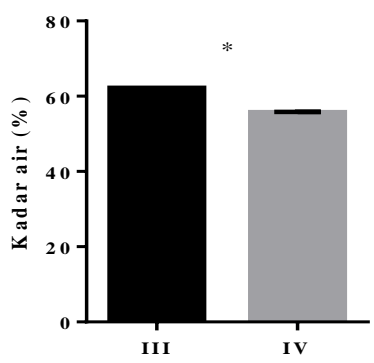

S a m pel

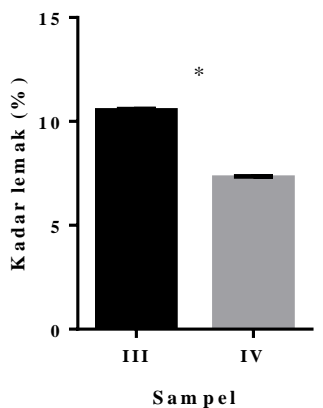

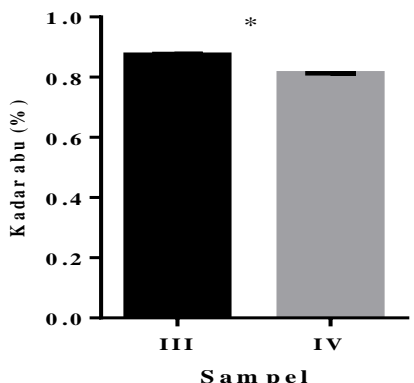

S a m p e

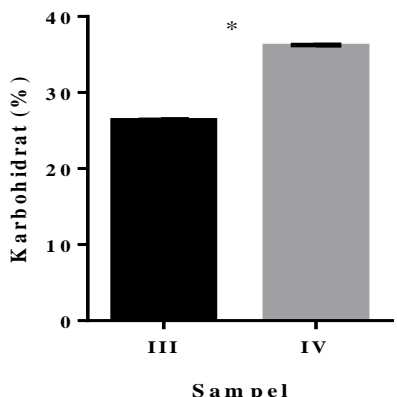

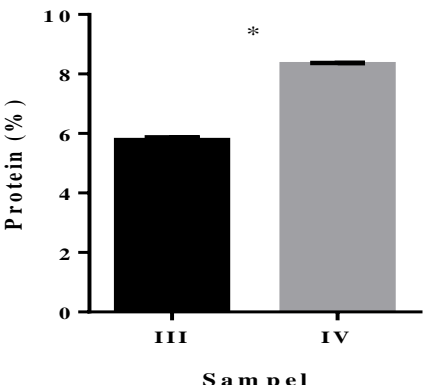

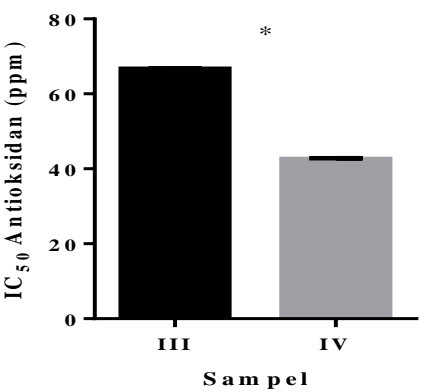

Gambar 2. Profil Kimia Es Krim dengan Penambahan Puree dan Bubuk Mandai

Keterangan: Standard error of mean (SEM) ditampilkan dengan simbol ( $\mathrm{T}$ ) di atas grafik. * menunjukan perbedaan signifikan pada taraf $\mathrm{P}<0,05$.
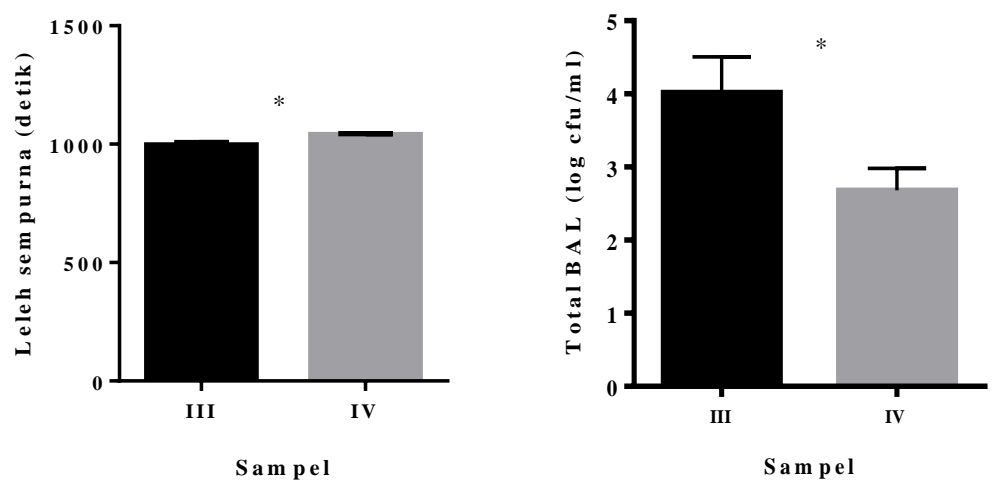

Gambar 3. Daya leleh dan total Bakteri Asam Laktat dari es krim puree dan bubuk mandai 
Keterangan: Standard error of mean (SEM) ditampilkan dengan simbol $(\mathrm{T})$ di atas grafik. * menunjukan perbedaan signifikan pada taraf $\mathrm{P}<0,05$.

\section{Daya Leleh dan Total Bakteri Asam Laktat}

Profil daya leleh es krim pada suhu $28 \pm 2{ }^{\circ} \mathrm{C}$ dengan penambahan puree atau bubuk mandai cempedak adalah cenderung sama, yaitu sekitar 1000 detik (16-17 menit). Menurut SNI No. 01-3713-1995, kisaran pelelehan yang baik pada es krim adalah 15-25 menit (BSN, 1992). Ini berarti es krim dengan penambahan puree atau bubuk mandai cempedakmasih memenuhi kriteria produk yang baku.

Penambahan puree mandai cempedak memiliki konsentrasi BAL yang lebih tinggi dibandingkan pada es krim dengan penambahan bubuk mandai. Maksud dari penambahan puree maupun bubuk mandai cempedak adalah untuk meningkatkan kemampuan probiotik dari es krim dan kemampuan antioksidatifnya (Nousia et al., 2010;Çamet al., 2014), yaitu kemampuan mandai cempedak sebagai salah satu agen probiotik telah dievaluasi oleh peneliti sebelumnya (Emmawati dkk, 2015).

Untuk dapat dikatakan sebagai probiotik, strain BAL yang digunakan harus mampu bertahan hidup melewati asam lambung dalam jumlah koloni yang signifikan. Penggunaan kultur pemula yang tepat adalah salah satu upaya untuk mendukung klaim sifat probiotik dari produk turunan mandai cempedak (Rahmadi dkk, 2017).

Menariknya, pada es krim dengan bahan baku bubuk mandai cempedak ditemukan BAL dengan konsentrasi mendekati 3 skala log cfu/mL (Gambar 3). Kemampuan bertahan kultur BAL pada es krim bubuk mandai cempedak perlu untuk diteliti lebih lanjut. Akan tetapi,fenomena ini tidak asing, mengingat BAL dapat bertahan di dalam proses spray dan freeze drying dari yoghurt (Chutrtong, 2015).

\section{Penerimaan Konsumen terhadap Aroma, Tekstur, dan Rasa}

Berdasarkan kuisoner yang disebarkan pada masyarakat umum, tingkat konsumsi es krim adalah sangat sering untuk 35 panelis, sering untuk 17 orang, jarang untuk 6 orang dan sangat jarang atau tidak pernah untuk 2 orang. Untuk es krim dengan flavor khas tropis yang pernah dicicipi adalah durian dengan jumlah 26 panelis, pisang dengan jumlah 22 panelis, nangka dengan jumlah 12 panelis. Sementara, es krim rasa cempedak belum pernah ditemukan di pasar komersial (Gambar 4).

Penilaian panelis terhadap es krim puree mandai cempedak mendapatkan nilai kesukaan aroma sebesar 3,35 $\pm 0,54$ dengan skala suka. Hasil ini tidak berbeda nyata $(P>0,05)$ dengan es krim komersil dengan memperoleh nilai kesukaan 3,51 $\pm 0,71$ dengan skala sangat suka. Es krim dengan penambahan bubuk mandai cempedak memperoleh nilai

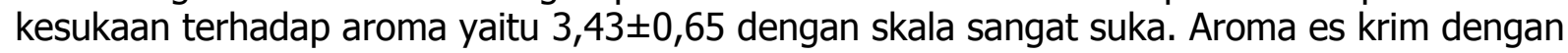
penambahan bubuk mandai cenderung disukai karena aroma khas cempedak lebih nyata pada es krim dengan penambahan puree mandai. Es krim dengan penambahan puree

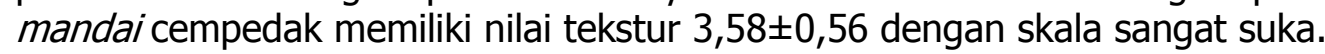

Angka ini menyerupai penerimaan terhadap tekstur dari es krim komersial. Nilai kesukaan terhadap tekstur es krim bubuk mandai cempedak berbeda nyata $(P<0.05)$ dengan nilai kesukaan $3,10 \pm 0,65$ atau jatuh dalam kategori suka. Penilaian panelis terhadap rasa es krim dengan penambahan puree mandai cempedak mendapatkan nilai kesukaan yang tidak berbeda nyata dengan es krim komersial pada skala sangat suka. Nilai kesukaan terhadap rasa es krim bubuk mandai cempedak jatuh dalam kategori agak suka dengan nilai $2,93 \pm 0,78$. Rasa yang ditimbulkan es krim dengan penambahan bubuk mandai sedikit kelat dan pahit di lidah diduga karena kandungan tanin yang terdapat pada bubuk mandai lebih tinggi dari kandungan tanin yang terdapat pada puree mandai (Gambar 5). Penggunaan pemanis yang berbeda, misalnya sukralosa dan aspartam (Nousia et al., 2010), dapat 
menghilangkan after taste yang kurang diterima, sebagaimana telah diteliti sebelumnya (Karamanet al., 2014).

\section{Kemampuan Bersaing dan Harga Es Krim}

Berdasarkan hasil kuisoner yang telah diisi oleh panelis dapat disimpulkan bahwa es krim yang diujikan mampu bersaing dengan produk komersial dengan jumlah panelis yang menjawab setuju (ya) sebanyak 37 orang dengan alasan bahwa rasa es krim dengan penambahan puree atau bubuk mandai cempedak mempengaruhi rasa dan aroma khas cempedak, sehingga rasa lebih dapat diterima dan dapat menjadi pilihan bagi penggemar es krim. Panelis yang menjawab tidak setuju (tidak) sebanyak 23 orang dengan alasan bahwa perlu diolah lebih baik lagi untuk melembutkan tekstur es krim yang belum mampu bersaing dengan es krim komersial. Perbaikan tekstur produk dapat dilakukan dengan penggunaan freezer yang lebih sesuai, yaitu pada suhu $-27 \pm 2{ }^{\circ} \mathrm{C}$ dibandingkan saat ini pada suhu $16 \pm 2^{\circ} \mathrm{C}$ (Buyck et al., 2011). Harga yang sesuai dengan produk es krim puree atau bubuk mandai cempedak dengan kemasan ukuran $200 \mathrm{~mL}$ yaitu $>$ Rp 5.000 dipilih oleh 16 panelis, Rp 10.000 dipilih oleh 19 panelis, >Rp 15.000 dipilih oleh 15 dan >Rp 20.000 dipilih oleh 10 panelis. Dari parameter harga, sebagian besar panelis (50 panelis), atau sekitar $83,33 \%$ dari total responden, memilih harga jual kurang dari Rp. 20.000.
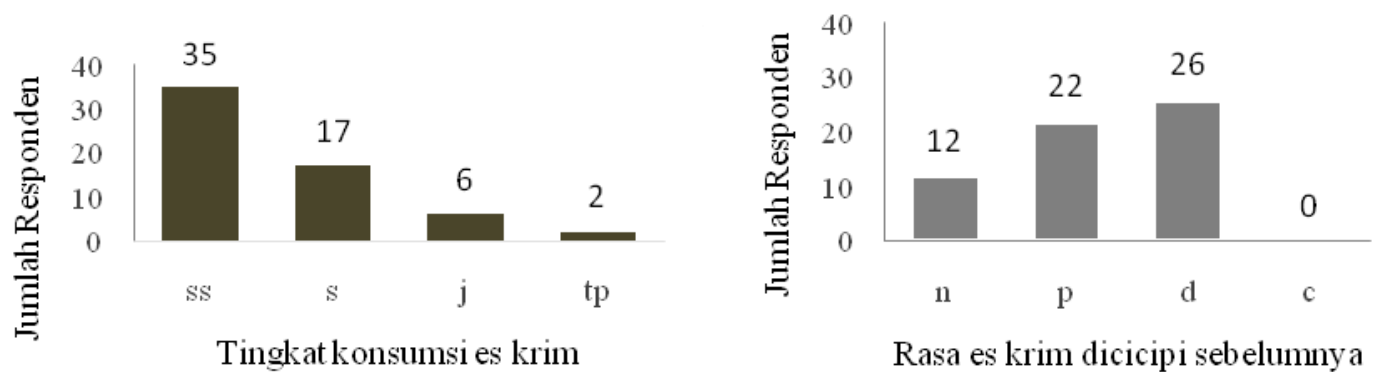

Gambar 4. Tingkat konsumsi es krim dan rasa es krim yang pernah dicicipi sebelumnya

Keterangan: Total panelis adalah 60 orang. (ss) sangat sering (s) sering (j) jarang, dan (tp) sangat jarang atau tidak pernah. Jenis rasa es krim yang pernah dicicipi adalah ( $n$ ) nangka, ( $p$ ) pisang (d) durian,dan (c) cempedak.

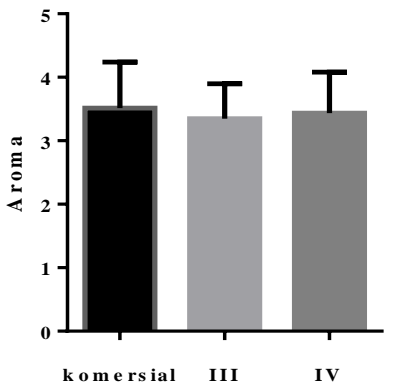

S a m pel

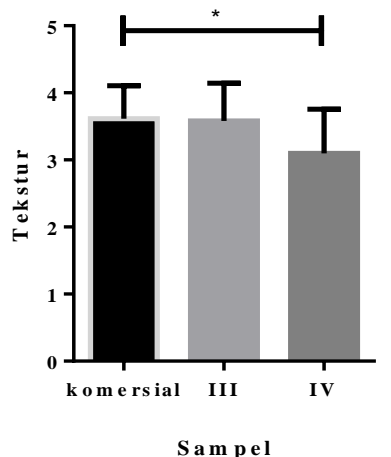

S a m pel

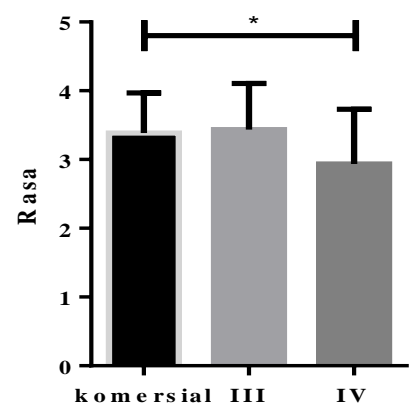

S a m pel

Gambar 5. Hedonik aroma, teksur, dan rasa es krim dengan penambahan puree dan bubuk mandai cempedak.

Keterangan: Skala hedonik 1-4 (tidak suka, agak suka, suka, dan sangat suka). Standard error of mean (SEM) ditampilkan dengan simbol $(\mathrm{T})$ di atas grafik.* menunjukkan perbedaan nyata pada taraf $(\mathrm{p}<0,05)$. Jumlah panelis adalah 60 orang. Pembanding komersial adalah es krim rasa nangka. 

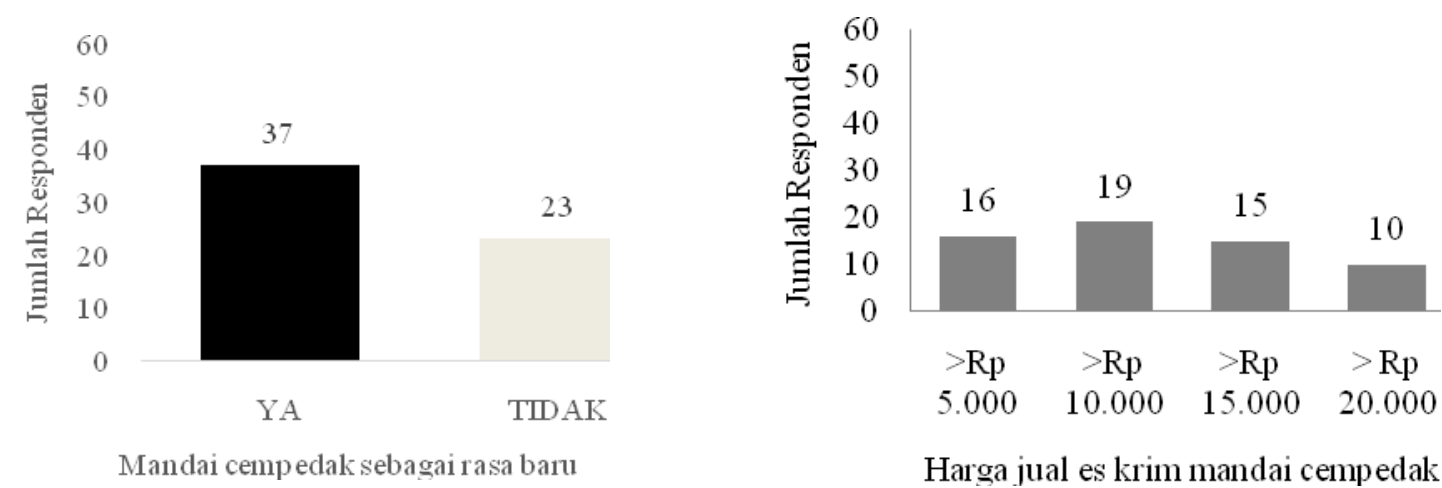

Gambar 6. Penerimaan terhadap mandai cempedak sebagai rasa baru dan harga jual es krim

Keterangan: Jumlah panelis adalah 60 orang

\section{KESIMPULAN}

Es krim dengan cita rasa baru yang berasal dari hasil fermentasi cempedak, atau dikenal dengan mandai cempedak memiliki potensi untuk dipasarkan berdasarkan hasil penelitian ini. Penggunaan puree mandai cempedak pada konsentrasi $100 \mathrm{~g}$ per formula merupakan pilihan konsumen yang secara hedonik mampu bersaing dengan produk komersial yang diujikan. Daya leleh es krim mandai cempedak berkisar 16 s.d. 17 menit. Karakteristik es krim puree mandai cempedak adalah kadar air sebesar 62,25 $\pm 0,07 \%$, kadar abu sebesar 0,874 $\pm 0,002 \%$, kadar protein sebesar 5,78 $\pm 0,09 \%$, kadar lemak sebesar $10,53 \pm 0,06 \%$, kadar karbohidrat sebesar $26,35 \pm 0,05 \%$, dan total BAL sekitar 4 skala log $\mathrm{cfu} / \mathrm{mL}$. Sementara, untuk produk es krim dengan penambahan bubuk mandai cempedak perlu untuk diperbaiki penerimaan konsumennya. Karakteristik es krim puree mandai cempedak adalah kadar air sebesar $55,77 \pm 0,06 \%$, kadar abu sebesar 0,812 $\pm 0 \%$, kadar

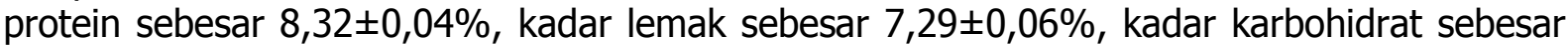
$36,12 \pm 0,12 \%$, dan total BAL mendekati 3 skala log cfu/mL. Harga jual per kemasan $200 \mathrm{~mL}$ tidak melebihi Rp. 20.000.

\section{UCAPAN TERIMA KASIH}

Peneliti mengucapkan terima kasih kepada DRPM Dikti atas pendanaan riset melalui skema PSNI tahun 2018.

\section{DAFTAR PUSTAKA}

[BSN] Badan Standardisasi Nasional. 1992. SNI01-2891-1992: Cara Uji Makanan dan Minuman, Jakarta: Badan Standarisasi Nasional.

[BSN] Badan Standardisasi Nasional. 1995. SNI 01-3713-1995. Tepung Es Krim. Jakarta: Badan Standardisasi Nasional.

Buyck, J.R., R.J. Baer, J. dan Choi. 2011. Effect of storage temperature on quality of light and full-fat ice cream.Journal of Dairy Science94(5): 2213-2219.

Cakmakci, S., E.F. Topdaas, P. Kalin, H. Han, P. Sekerci, L.P. Kose, dan I. Gulcin. 2015. Antrioxidant capacity and functionality of oleaster (Elaeagnus angustifoloa L.) flour and cust in a new kind of fruity ice cream. International Journal of Food Science and Technology50: 472-481.

Çam, M., N.C. İçyer, dan F. Erdoğan. 2014.Pomegranate peel phenolics: Microencapsulation, storage stability and potential ingredient for functional food development. LWT-Food Science and Technology55(1): 117:123. 
Chauliyah, A.I.N. dan E.A. Murbawani. 2015.Analisis Kandungan Gizi dan Aktivitas Antioksidan Es Krim Nanas Madu. Tugas Akhir. Universitas Diponegoro, Semarang.

Chutrtong, J. 2015.Survival of Probiotic Bacteria in Freeze - Dry Yogurt Starter Cultures Storage at 4 and 30 Degree Celsius.Procedia - Social and Behavioral Sciences 191: 2219-2225.

Dertli, E., O.S. Toker, M.Z. Durak, M.T. Yilmaz, N.B. Tatlisu, O. Sadgic, dan H. Cankurt. 2016.Development of a fermented ice-cream as influenced by in situexopolysaccharide production: Rheological, molecular, microstructural and sensory characterization. Carbohydrate Polymers 136:427-440.

El-Nagar, G., G. Clowes, C.M. Tudorică, V. Kuri, dan C.S. Brennan. 2016. Rheological quality and stability of yog-ice cream with added inulin. International Journal of Dairy Technology55: 89-93.

Emmawati, A., B.S.L.S. Jenie, L. Nuraida, dan D. Syah.2015. Karakterisasi isolat bakteri asam laktat dari mandai yang berpotensi sebagai probiotik. Agritech 35(2):146-155.

Fardiaz, S. 1993. Analisis Mikrobiologi Pangan. Jakarta: PT. Raja Grafindo Persada.

Fonseca, F.G.A., E.A. Esmerino, E.R.T. Filho, J.P. Ferraz, A.G.C. Cruz, dan H.M.A. Bolini. 2016.Novel and successful free comments method for sensory characterization of chocolate ice cream: A comparative study between pivot profile and comment analysis. Journal of Dairy Science. 99(5): 3408-3420.

Karaman, S., O.S. Toker, F. Yuksel, M. Cam, A. Kayacier, dan M. Dogan. 2014.Physicochemical, bioactive, and sensory properties of persimmon-based ice cream: Technique for order preference by similarity to ideal solution to determine optimum concentration, Journal of Dairy Science. 97(1): 97-110.

Molyneux P. 2004. The use of the stable free radical diphenylpicryl-hydrazyl (DPPH) for estimating antioxidant activity. J Sci Technol. 26(2): 211-219.

Nousia, F.G., P.P. Androulakis,dan D.J. Fletouris. 2010. Survival of Lactobacillus acidophilus LMGP-21381 in probiotic ice cream and its influence on sensory acceptability. International Journal of Dairy Technology 64(1), 130-136.

Nur, H. S. 2009. Suksesi Mikroba dan Aspek Biokimia Fermentasi Mandai dengan Kadar Garam Rendah. Makara Sains13: 13-16.

Oksilia, M. I., Syafutri, dan E. Lidiasari. 2012.Karakteristik Es Krim Hasil Modifikasi Dengan Formulasi Bubur Timun Suri (Cucumis melo) dan Sari Kedelai. Jurnal Teknologi dan Industri Pangan. 23(1):18-19.

Ordonez, A., I.J. Jeon, dan H.A. Roberts.2000. Manufacture of Frozen Yogurt With Ultrafiltered Milk and Probiotic Lactic Acid Baceria. Journal of Food Processing and Preservation, 24(2): 163-176.

Patel, I.J., C.N. Dharaiya, dan S.V. Pinto. 2015. Development of Technology for manufacture of ragi cream. Journal of Food Science and Technology 52(7): 4015-4028.

Rahmadi, A., K. Sari, S. Satrio, N. Khoiriyah, F. Handayani, A. Emmawati dan Yuliani. 2017. Profil Perubahan Populasi BAL, pH, Kadar Flavonoid, dan Potensi Antivitas Antioksidan dari Fermentasi Mandai Cempedak Hgenis Tanpa Garam. ProsidingSeminar Nasional PATPI Lampung Buku 2: 811-817.

Silva, P.D.L., M.F. Bezerra, K.M.O. Santos, dan R.T.P.C. Correia.2015. Potentially probiotic ice cream from goat's milk: Characterization and viability during processing, storage and simulates gastrointestinal conditions. LWT-Food Science and Technology62(1): 452457.

Soukoulis, C. dan C. Tzia. 2018. Grape, raisin and sugarcane molasses as potential partial sucrose substitutes in chocolate ice cream: A feasibility study.Indonesian Dairy Journal76: 18-29. 
Soukoulis, C. dan C. Tzia. 2008. Impact of the acidification process, hydrocolloids and protein fortifiers on the physical and sensory properties of frozen yogurt. International Journal of Dairy Technology61(2) 170-177.

Soukoulis, C., E. Lyroni, dan C. Tzia.2010. Sensory profiling and hedonic judgement of probiotic ice cream as a function of hydrocolloids, yogurt and milk fat content. LWTFood Science and Technology 43(9): 1351-1358.

Tekin, E., S. Sahim, dan G. Sumnu. 2017. Physicochemical, rheological, and sensory properties of low-fat ice cream designed by double emulsions. European Journal of Lipid Science and Technology 119(9): 1600505. 